\title{
The Interrelationship between Military Expenditure and External Debt: Patterns of Causation in Northern Africa Countries
}

\author{
*Andreas G. Georgantopoulos, Anastasios D. Tsamis \\ Panteion University of Political and Social Sciences, Athens, Greece \\ *ageorgantos@yahoo.com
}

\begin{abstract}
It is supported by academics and scholars that defense expenditure can significantly affect a country's economic growth and in some cases it influences external debt having implications in various macroeconomic indicators. However, relevant empirical studies have produced contradictory evidence while the literature in this field remains relatively poor. In this spirit, this survey investigates the causal links between military expenditure and external debt for four emerging Northern Africa countries (i.e. Egypt, Tunisia, Algeria and Morocco) during the period 1988-2009. Empirical findings on the long-term relationship between the tested variables are based on cointegration test. The Granger Causality test results using Vector Auto Regression (VAR) estimates and the Error Correction Model imply that there is no dynamic causal link between military expenditure and external debt for Tunisia, Algeria and Morocco. On the other hand regarding Egypt, results imply that a strong unidirectional causality exists running from defense expenditure to external debt. Collectively, empirical calculations show that military burden do not have any significant impact on most Northern Africa countries. The only exception is the case of Egypt; empirical results show that military expenditure robustly affect the country's external debt. These are the only findings provided from this study that validate the hypothesis that military burden may be important in determining the evolution of debt in developing countries.
\end{abstract}

Keywords: Northern Africa, military expenditure, external debt, cointegration, Granger causality.

\section{Introduction}

Brief Review of Northern Africa Economies: Northern Africa is the northernmost region of the African continent, linked by the Sahara to Sub-Saharan Africa. According to United Nations (UN) definition, Northern Africa is consisted by seven countries (or territories); Algeria, Egypt, Libya, Morocco, Sudan, Tunisia, and Western Sahara. The economy of Egypt depends mainly on agriculture, media, petroleum exports, and tourism. Moreover workers' remittances also play an important role since more than three million Egyptians are working abroad, mainly in Saudi Arabia, the Persian Gulf and various European countries. The government has invested in communications and physical infrastructure. Egypt has received U.S. foreign aid (since 1979, an average of $\$ 2.2$ billion per year) and is the third-largest recipient of such funds from the United States following the Iraq war. However, the country's main revenues are gained from tourism as well as traffic that run through the Suez Canal. The economy of Egypt is under rapid economic transformations, which is evidenced by recent International Monetary Fund (IMF) reports that rate Egypt as one of the top countries in the world undertaking economic reforms. Some major economic reformations taken by the governments since 2003 include significant reductions of customs and tariffs. Corporate taxes decreased from 40 percent to the current 20 percent due to a new taxation law implemented in 2005, resulting in a stated 100 percent increase in tax revenue by the year 2006. Foreign direct investment (FDI) into Egypt has increased considerably in the past few years, exceeding 6 billion U.S. dollars in 2006, due to the recent economic liberalization and privatization measures. The Egyptian Armed forces have combined troop strength of around 450,000 active personnel. The United States of America provide an annual military assistance, which in 2009 amounted to 1.3 billion U.S. dollars (inflation adjusted US\$1.33 billion in 2011).

On the other hand, the economy of Tunisia depends mainly on agriculture, mining, manufacturing, petroleum products and tourism. In 2008 Tunisia had a GDP of 41 billion U.S. dollars. The country also has one of Africa and the Middle East's highest per-capita GDPs (PPP). The agricultural sector stands for 11.6 percent of the GDP, industry 25.7 percent, and services 62.8 percent. The industrial sector remains at a moderate level mainly depending on clothing manufacturing, production of car parts and electric machinery. Although Tunisia managed an average 5 percent growth during the 2000 's, it continues to 
suffer from high unemployment rates especially among youth. The European Union is by far Tunisia's first trading partner, currently accounting for 72.5 percent of Tunisian imports and 75 percent of Tunisian exports. Moreover, the country is a distinguished EU's trading partner ranking $30^{\text {th }}$ in the relevant list of EU's largest trading partners. The military forces of Tunisia consist of 27,000 personnel equipped with 84 main battle tanks and 48 light tanks. The navy numbers 4,800 personnel, 25 patrol boats and 6 other craft. The air force has 4,000 personnel, 27 combat aircraft and 43 helicopters. In addition, paramilitary forces consisted of a 12,000-member national guard (Hackett, 2008).

Regarding Algeria, the country's economy is mostly relied on the petroleum refining sector, accounting for roughly 60 percent of budget revenues, 30 percent of GDP, and over 95 percent of export earnings. Ranking $14^{\text {th }}$ in petroleum reserves (i.e. 11.8 billion barrels) the country is considered a major energy producer. During the mid-1990's Algeria enjoys rapid economic growth, mainly due to structural reformations supported by the International Monetary Fund (IMF) and debt rescheduling from the Paris Club. In the early 2000's, the economy of Algeria benefited from an increase in oil prices and the government's tight fiscal policy, leading to a large increase in the trade surplus, record highs in foreign exchange reserves, and reduction in foreign debt. The government of Algeria strived to diversify the economy by attracting FDI to sectors other than the energy sector. Nevertheless, these efforts have had little success in reducing high unemployment and improving living standards. In 2001, the government along with the European Union signed the Association Treaty, which eventually lowered tariffs and stimulated trade. In March 2006, Russia agreed to erase $\$ 4.74$ billion of Algeria's Soviet-era debt. Algeria also decided in 2006 to pay off its full 8 billion U.S. dollars debt to the Paris Club group of rich creditor nations before schedule. These tactics reduced the Algerian foreign debt to less than 5 billion U.S. dollars in the end of 2006. According to Hackett (2008) total military personnel include 147,000 active, 150,000 reserve, and 187,000 paramilitary staff. The total military expenditure in 2006 was estimated variously at 2.7 percent of GDP (3,096 million), or 3.3 percent of GDP. The former Soviet Union and the Republic of China has been its primary military supplier.

Morocco's economy is considered a relatively globalized economy. Since 1993, the country has followed a privatization policy of certain economic sectors which used to be in the hands of the government. Government reforms and steady yearly growth in the region of 4-5\% from 2000 to 2007 helped the Morocco's economy to become much more robust compared to the recent past. Economic growth is far more diversified, with new service and industrial centers, like Casablanca and Tangier, developing. The agriculture sector is being rehabilitated. In combination with good rainfalls, agriculture led to a growth of over 20 percent in 2009, consisting it one of the country's major resources, along with phosphates and tourism. Industry and mining contribute about one-third of the annual GDP. Morocco is the world's thirdlargest producer of phosphorus and the price fluctuations of phosphates on the international market greatly influence Morocco's economy. Compulsory military service in Morocco has been suppressed since September 2006, and the country's reserve obligation lasts until age 50. Morocco's military consists of the Royal Armed Forces, a small navy and air force and the Auxiliary Forces. Internal security is generally effective, while acts of political violence are rare.

Military Expenditures and External Debt in Northern Africa Countries: According to Dunne et al. (2004), the relationship between military expenditures and external debt can be of two forms. As a budget item, military expenditure creates the need for funding. If a rise in military expenditure cannot be financed through taxation, it creates a deficit which may be financed in four different ways: (i) printing money, (ii) using foreign exchange reserves, (iii) borrowing abroad or (iv) borrowing domestically. However, each of these methods has some limits and implications, which are widely discussed in the literature and, while interrelated, are associated with particular macroeconomic imbalances: printing money with inflation; using foreign reserves with the onset of exchange crises; foreign borrowing with an external debt crisis (Fischer and Easterly, 1990). High public sector deficits relative to GDP, therefore, potentially create a need for foreign borrowing and external debt accumulation, particularly when the means to finance deficits domestically is limited.

Hence, there is a possibility of a relatively close relation between the deficits and foreign borrowing in developing countries, where the ability of using tax revenues to finance public expenditures is likely to be limited, money creation is likely to have already been misused, financial markets are relatively thin and domestic borrowing possibilities are relatively restricted (Dunne et al. 2004). A component of military spending will be allocated to pay for arms imports, which will create the need for foreign exchange. If 
there seems to be a lack of foreign exchange, the economy will need to obtain it from external sources, usually by borrowing. It is also possible that depreciations in the currency could lead to increases in foreign exchange requirements.

The key question in analyzing the effect of military expenditure on debt then, is how such expenditure is financed. If it is through higher tax revenues or lower government spending in other areas, it will not create a deficit; if higher military spending does create a deficit, this may or may not be financed through external debt. In the case of arms imports, the question is whether they can be funded through export earnings or existing reserves, or whether they require new credit. Figure 1 illustrates the trends in military burden as a percentage of GDP for the sample of four Northern Africa countries, during the period 1988-2009. In the late 1980's Egypt presents by far the highest military expenditure to GDP ratio followed by Morocco, Tunisia and Algeria. However, this high rate tends to decrease throughout the years and most Northern Africa countries seem to converge in the range between $2.4 \%$ and $4.2 \%$. Tunisia, historically presents the lowest defense to GDP ratio during the whole tested period starting from $2.3 \%$ in 1988 and steadily declining since then.

Figure 1: Trends in Military Expenditure to GDP (1988 - 2009)

(Military Expenditure to GDP)

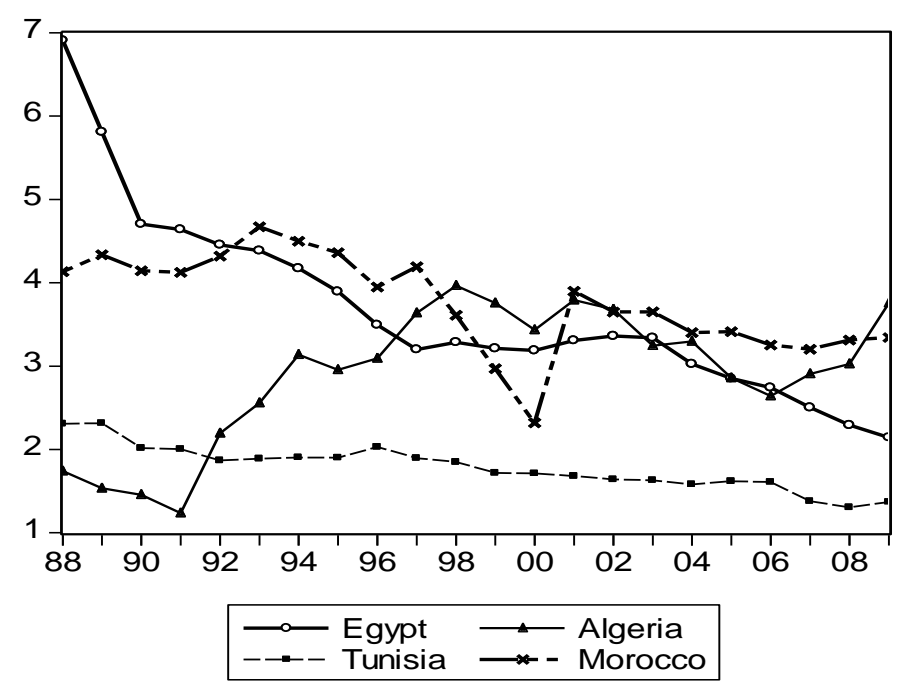

Source: Stockholm International Peace Research Institute (SIPRI) and World Bank Indicators

On the other hand, Egypt also presents the highest external debt to GDP ratio in the late 1980's (i.e. 132 percent of GDP in 1988) as shown in Figure 2 followed by Morocco, Tunisia and Algeria. However, during the tested period this ratio shows a downward trend for most tested countries except Tunisia, where it remains in the range between 60-80 percent of GDP with Egypt and Algeria having the most impressive external debt reductions achieved.

Figure 2: Trends in External Debt to GDP (1988 - 2009)

(External Debt to GDP)

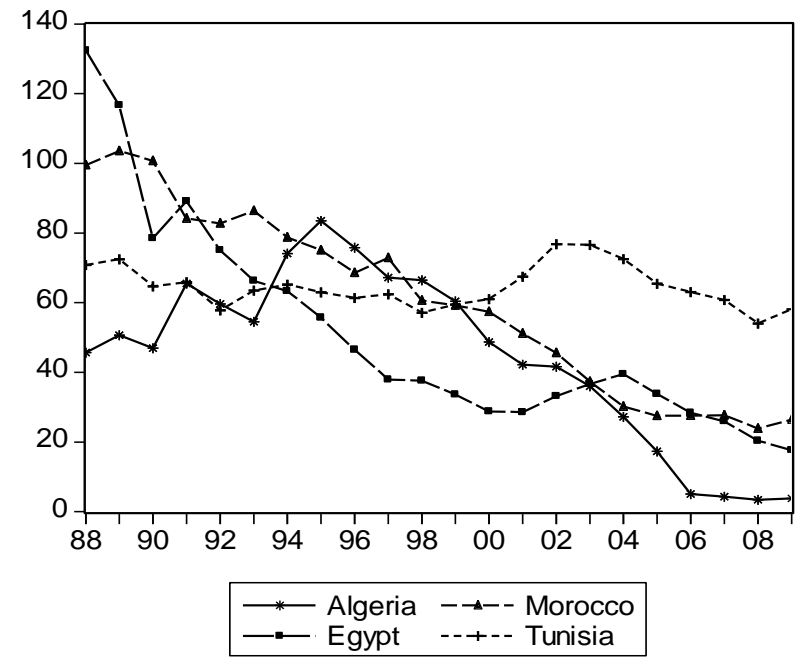




\section{Source: World Bank Indicators (World Bank Database)}

In this spirit, the central objective of this study is to investigate the causal links between military expenditures and external debt for four emerging Northern Africa economies (Egypt, Tunisia, Algeria and Morocco). This paper is motivated by a number of factors. First, there are no other published studies investigating the presence of interdependence between military burden and external debt for these Northern Africa countries to the best of our knowledge. Second, it enriches the very few existing literature on the causal links between defense expenditure and external debt. Third, it covers a period, which includes some of the most important macroeconomic and political transformations leading to more open and therefore more globalized and modern economies for Northern Africa countries. The rest of the paper is organized as follows. Section 2 briefly reviews the literature. Section 3, presents the data and methodology employed. Section 4 presents the empirical results, while concluding remarks with some policy implications are presented in Section 5.

\section{Literature Review}

There is a lack of literature covering the impact of military burden on developing country debt. Brzoska (1983) Looney $(1987,1989,1998)$, Dunne et al. (2004), Feridun (2005) have attempted to investigate the potential effect of military spending on developing country debt, and provided some useful initial findings, having the need to understand better the dynamics within the individual countries as a central objective of their study. The results present contradictory evidence. Collectively, most studies do tend to show an insignificant or negative impact between the two macroeconomic variables (Dunne, 1996).

Furthermore, surveys investigating the interdependence between military expenditure and external debt are even more limited. It is suggested by some authors, starting with Brzoska (1983), that military expenditure is a key variable in explaining the rise of foreign debt in a number of developing countries, indicating that this has led to reduced economic growth. Looney and Frederiksen (1986) concluded that the impact of high external borrowing due to defense spending on a country's overall growth performance and resource allocation depends on the country's capacity for international borrowing. Looney (1989) and Looney and Frederiksen (1986) allocated developing countries into groups based on their capability to raise external debt, using factor analysis and discriminant analysis. They suggest that unconstrained countries will be able to support higher level of arms imports. Looney $(1989,1998)$ then drew attention to the weakness of the literature on the motives of debt accumulation and pointed out the significance of military expenditures, specifically arms imports for the Third World indebtedness. In his empirical analysis, Looney (1989) developed three models, for military expenditure (ME), Public External Debt (PDB), Arms Imports (AI) and ran regressions for the whole sample, using two-stage least squares.

In a more recent literature contribution Sezgin (2004) considered the relation between military debt and arm imports for the case of Turkey. As direct data are not available on cash payments for arms imports and military debt, he resorted to an indirect analysis and presented the likely impact of defense on external indebtedness via a model of debt and arms imports (in fact arms transfers to Turkey). To do this, he estimated a model where the growth of external debt was a function of the growth of real GNP, the growth of merchandise imports, the growth of merchandise exports, the growth of real defense expenditures, the growth of real defense equipment expenditures and the growth of real arms imports. He found arms imports to be the only substantial defense related variable, although it was only meaningful at a weak level.

Panel data techniques were used by Dunne et al. (2004), in order to explore the effect of military expenditure on debt using a sample of industrializing economies around the world between 1960 and 2000. Their model estimates the share of external debt in GDP as a function of GDP growth, exports as a share of GDP, international reserves as a share of GDP, and military expenditure as a share of GDP (military burden). GDP growth, exports and reserves are included as they may measure the ability of the economy to finance military expenditure and arms imports without resorting to borrowing. In a static panel data model, they find military burden to have a positive but insignificant effect on the debt burden, while GDP growth and reserves have a significant negative effect, and exports a significant positive effect. 
However, when a dynamic panel data model was created and estimated, using the Arellano-Bond (1991) GMM estimators, a significant positive effect of military burden was found. GDP growth was still significant and negative, indicating that a strong economy makes it easier to manage debt, while the export and reserve variables became insignificant. The lagged dependent variable was found robustly significant and positive.

\section{Data and Methodology}

This survey investigates the causal links between military expenditures as a percentage of Gross Domestic Product (GDP) and external debt to GDP by employing a data set for Northern Africa countries (i.e. Egypt, Tunisia, Algeria and Morocco) during the period 1988-2009. All selected data are in annual base and gathered from reliable sources; Military expenditures (ME) data are derived from the Stockholm International Peace Research Institute (SIPRI) and the World Bank Indicators (i.e. the World Bank database), while external debt (ED) data are gathered from the World Bank Indicators. Authors' calculations are conducted using the E-views 7.1 software (2010). Moreover, all data are transformed into logarithmic returns in order to achieve mean-reverting relationships, and to make econometric testing procedures valid.

Military expenditures (ME) data from SIPRI are derived from the North Atlantic Treaty Organization (NATO) definition, which includes all current and capital expenditures on the armed forces, including peacekeeping forces; defense ministries and other government agencies engaged in defense projects; paramilitary forces, if these are judged to be trained and equipped for military operations; and military space activities. Such expenditures include military and civil personnel, including retirement pensions of military personnel and social services for personnel; operation and maintenance; procurement; military research and development; and military aid (in the military expenditures of the donor country). Excluded are civil defense and current expenditures for previous military activities, such as for veterans' benefits, demobilization, conversion, and destruction of weapons.

Total external debt (ED) is defined as debt owed to nonresidents repayable in foreign currency, goods, or services. Total external debt is the sum of public, publicly guaranteed, and private nonguaranteed longterm debt, use of IMF credit, and short-term debt. Short-term debt includes all debt having an original maturity of one year or less and interest in arrears on long-term debt. Gross Domestic Product (GDP) is the sum of gross value added by all resident producers in the economy plus any product taxes and minus any subsidies not included in the value of the products. It is calculated without making deductions for depreciation of fabricated assets or for depletion and degradation of natural resources. The econometric methodology firstly examines the stationary properties of the univariate time series. Augmented DickeyFuller (ADF) test has been used to test the unit roots of the concerned time series variables (Dickey and Fuller, 1979). It consists of running a regression on the first difference of the series against the series lagged once, lagged difference terms, and optionally, by employing a constant and a time trend. This can be expressed as:

$$
\Delta z_{t}=\Gamma_{1} \Delta z_{t-1}+\ldots+\Gamma_{k-1}^{(1)} \Delta z_{t-k-1} \Pi z_{t-1}+\mu+\varepsilon_{t}:
$$

The test for a unit root is conducted on the coefficient of $\left(\mathrm{y}_{\mathrm{t}-1}\right)$ in the regression. If the coefficient is significantly different from zero then the hypothesis that (y) contains a unit root is rejected. Rejection of the null hypothesis implies stationarity. Furthermore, the time series has to be examined for cointegration. Cointegration analysis helps to identify long-run economic relationships between two or several variables and to avoid the risk of spurious regression. Cointegration analysis is important because if two non-stationary variables are cointegrated, a Vector Auto regression (VAR) model in the first difference is misspecified due to the effect of a common trend. If a cointegration relationship is identified, the model should include residuals from the vectors (lagged one period) in the dynamic Vector Error Correcting Mechanism (VECM) system. In this stage, the Johansen (1988) cointegration test is used to identify a cointegrating relationship among the variables. Within the Johansen multivariate cointegrating framework, the following system is estimated:

$$
\Delta z_{t}=\Gamma_{1} \Delta z_{t-1}+\ldots+\Gamma_{k-1} \Delta z_{t-k-1} \Pi z_{t-1}{ }^{\mathrm{t}} \neq \mathcal{k}_{b} \cdot \mathrm{T}^{\mathrm{T}} \varepsilon_{t}:
$$


where, $\Delta$ is the first difference operator, $\mathrm{z}^{\prime}$ denotes a vector of variables, $\varepsilon_{\mathrm{t}} \sim \mathrm{n}$ iid $\left(0, \sigma^{2}\right), \mu$ is a drift parameter, and $\Pi$ is a (p x p) matrix of the form $\Pi=\alpha \beta^{\prime}$, where $\alpha$ and $\beta$ are both (p x r) matrices of full rank, with $\beta$ containing the $r$ cointegrating relationships and $\alpha$ carrying the corresponding adjustment coefficients in each of the $r$ vectors. The Johansen approach can be used to carry out Granger causality tests as well. In the Johansen framework, the first step is the estimation of an unrestricted, closed p-th order VAR in k variables. Johansen (1988) suggested two tests statistics to determine the cointegration rank. The first of these is known as the trace statistic:

$$
N\left\{\operatorname{trace}\left(r_{0} / k\right)=-T \sum_{i=r_{0}+1}^{k} \ln \left(1-\hat{\lambda}_{i}\right)\right.
$$

Where, $\lambda$ are the estimated eigenvalues $\lambda_{1}>\lambda_{2}>\lambda_{3}>\ldots>\lambda_{\kappa}$ and $r_{0}$ ranges from zero to k- 1 depending upon the stage in the sequence. This is the relevant test statistics for the null hypothesis $r \leq r_{0}$ against the alternative $r \geq r_{0}+1$. The second test statistic is the maximum eigenvalue test known as $\lambda_{\max }$; we denote it as $\lambda_{\max }\left(\mathrm{r}_{0}\right)$. This is closely related to the trace statistic, but arises from changing the alternative hypothesis from $r \geq r_{0}+1$ to $r=r_{0}+1$ The idea is trying to improve the power of the test by limiting the alternative to a cointegration rank which is just by one more than the null hypothesis. The $\lambda_{\max }$ test statistic is:

$$
\lambda_{\max }\left(\mathrm{r}_{0}\right)=-\mathrm{T} \text { in }\left(1-\lambda_{\mathrm{i}}\right) \text { for } \mathrm{i}=\mathrm{r}_{0}+1
$$

The null hypothesis is that there are $r$ cointegrating vectors, against the alternative of $r+1$ cointegrating vectors. Johansen and Juselius (1990) indicated that the trace test might lack power relative to the maximum eigenvalue test. Based on the power of the test, the maximum eigenvalue test statistic is often preferred. According to Granger (1969), Y is said to "Granger-cause" X if and only if X is better predicted by using the past values of $Y$ than by not doing so with the past values of $X$ being used in either case. In short, if a scalar $Y$ can help to forecast another scalar X, then we say that $Y$ Granger-causes X. If $Y$ causes $X$ and $X$ does not cause $Y$, it is said that unidirectional causality exists from $Y$ to $X$. If $Y$ does not cause $X$ and $X$ does not cause $Y$, then $X$ and $Y$ are statistically independent. If $Y$ causes $X$ and $X$ causes $Y$, it is said that feedback exists between X and Y. Essentially, Granger's definition of causality is framed in terms of predictability.

To implement the Granger test, a particular autoregressive lag length $\mathrm{k}$ (or $\mathrm{p}$ ) is assumed and Models (5) and (6) are estimated by OLS:

(5)

$$
\begin{gathered}
X_{t}=\lambda_{1}+\sum_{i=1}^{k} \alpha_{1 i} \mathrm{X}_{t-i}+\sum_{i=1}^{k} b_{1 j} Y_{t-j}+\mu_{1 t} \\
Y_{t}=\lambda_{2}+\sum_{i=1}^{j=1} \alpha_{2 i} \mathrm{X}_{t-i}+\sum_{j=1} b_{2 j} Y_{t-j}+\mu_{2 t} \\
H_{0}: b_{i 1}=b_{i 2}=\ldots=b_{i k}=0, i=1,2 .
\end{gathered}
$$

Furthermore, an F-test is carried out for the null hypothesis of no Granger causality; where, the F statistic is the Wald statistic of the null hypothesis. If the F statistic is greater than a certain critical value for an $\mathrm{F}$ distribution, then we reject the null hypothesis that $\mathrm{Y}$ does not Granger-cause $\mathrm{X}$, which means Y Granger-causes X.

A time series with a stable mean value and standard deviation is called a stationary series. If $\mathrm{d}$ differences have to be made to produce a stationary process, then it can be defined as integrated of order d. Engle and Granger (1987) state that if several variables are all I(d) series, their linear combination may be cointegrated, that is, their linear combination may be stationary. Although the variables may drift away from equilibrium for a while, economic forces are expected to restore equilibrium. Thus, they tend to move together in the long run irrespective of short run dynamics. The definition of Granger causality is based on the hypothesis that X and Y are stationary or I (0) time series. Therefore, the fundamental Granger method for variables of I (1) cannot be applied. In the absence of a cointegration vector, with I (1) series, valid results in Granger causality testing are obtained by simply first differentiating the VAR model. With cointegration variables, Granger causality will require further inclusion of an error term in the stationary model in order to capture the short term deviations of series from their long-term equilibrium path. Hassapis et al. (1999) show that in the absence of cointegration, the direction of 
causality can be decided upon via standard F-tests in the first differenced VAR. The VAR in the first difference can be written as:

$$
\begin{array}{r}
N\left\{\Delta \mathrm{X}_{t}=\lambda_{1}+\sum_{i=1}^{k} \alpha_{1 i} \Delta \mathrm{X}_{t-i}+\sum_{j=1}^{k} b_{1 j} \Delta Y_{t-j}+\ell_{1 t}\right\}^{p} \\
N\left\{\Delta Y_{t}=\lambda_{2}+\sum_{i=1}^{p} \alpha_{2 i} \Delta \mathrm{X}_{t-i}+\sum_{j=1}^{p} b_{2 j} \Delta Y_{t-j}+\mu_{2 t}\right.
\end{array}
$$

\section{Empirical Results}

Table 1 reports the descriptive statistics for the data sample of the two macroeconomic variables and for all four tested Northern Africa countries. Overall calculations indicate that variables are not normally distributed and are characterized as leptokurtic and skewed.

Table 1: Descriptive Statistics

\begin{tabular}{lllllllll}
\hline \multirow{2}{*}{ Statistics } & Egypt & \multicolumn{2}{c}{ Tunisia } & \multicolumn{2}{c}{ Algeria } & \multicolumn{2}{c}{ Morocco } \\
& ED & ME & ED & ME & ED & ME & ED & ME \\
\hline Mean & 51.16170 & 3.677511 & 64.52968 & 1.782521 & 44.56811 & 2.904445 & 60.29728 & 3.761282 \\
Median & 37.77996 & 3.323472 & 63.28617 & 1.783461 & 47.85033 & 3.059532 & 59.91018 & 3.774454 \\
Maximum & 132.3959 & 6.906095 & 76.83707 & 2.314936 & 83.52277 & 3.965660 & 103.5432 & 4.670514 \\
Minimum & 17.64353 & 2.144738 & 53.99301 & 1.305517 & 3.432934 & 1.236116 & 23.84991 & 2.320651 \\
Std. Dev. & 30.81714 & 1.137685 & 6.163709 & 0.268424 & 24.97341 & 0.815345 & 26.73060 & 0.576145 \\
Skewness & -0.251577 & 1.197627 & 0.517267 & 0.178886 & -0.420905 & -0.717282 & 0.065420 & -0.529924 \\
Kurtosis & 1.933937 & 4.306580 & 2.548043 & 2.685292 & 2.071146 & 2.422323 & 1.702186 & 2.885426 \\
Jarque-Bera & 2.316090 & 2.150293 & 1.168314 & 0.208123 & 1.440462 & 2.192378 & 1.559653 & 1.041704 \\
Probability & 0.314100 & 0.33853 & 0.557576 & 0.901170 & 0.486640 & 0.334142 & 0.458486 & 0.594014 \\
\hline
\end{tabular}

Table 2 displays the estimates of the Augmented Dickey - Fuller (ADF) test in levels and in first differences of the data with an intercept, with an intercept and trend and with no intercept or trend. The tests have been performed on the basis of 5 percent significance level, using the MacKinnon Critical Values (MacKinnon, 1996). The lag length was determined using Schwarz Information Criterion (Schwartz, 1978). Initially, ADF test with an intercept implies that all variables are not stationary at levels even at 10 percent level of significance. However, at $1^{\text {st }}$ differences ME and ED are all stationary at an accepted significance level (i.e. 5 or 1 percent level) and for all tested countries. Similar results present the unit root test with an intercept and trend, since all variables present no significance at levels but at $1^{\text {st }}$ differences all variables are integrated of order one. Finally, ADF test with no intercept or trend reports that at levels none of the examined variables have a unit root. However, at $1^{\text {st }}$ differences all variables are stationary at 1 percent significance level except ME for Egypt which is integrated of orders one at 5 percent. Collectively, all test results imply that all variables are not stationary at levels at any accepted level of significance. These are stationary at $1^{\text {st }}$ differences. So, robust results derived from three forms of ADF test procedures all indicate that defense expenditure and external debt for the sample of four Northern Africa countries are integrated of order one i.e. I (1).

Table 2: Augmented Dickey - Fuller Unit Root Test Results

\begin{tabular}{llllllll}
\hline \multirow{2}{*}{ Country } & \multirow{2}{*}{ Variable } & \multicolumn{2}{c}{ Test with Intercept } & \multicolumn{2}{c}{$\begin{array}{l}\text { Test with } \\
\text { and Trend }\end{array}$} & \multicolumn{2}{c}{$\begin{array}{l}\text { Intercept } \\
\text { or Trend }\end{array}$} \\
\cline { 3 - 8 } & & Levels & 1st Diff. & Levels & 1st Diff. & Levels & 1st Diff. \\
\hline \multirow{2}{*}{ Egypt } & ED & -1.1804 & $-3.9458^{* * *}$ & -2.2284 & $-3.8713^{* *}$ & -1.4874 & $-2.8911^{* * *}$ \\
& ME & -0.6661 & $-3.1417^{* *}$ & -2.7212 & $-3.7452^{* *}$ & -1.8849 & $-2.5123^{* *}$ \\
\multirow{2}{*}{ Tunisia } & ED & -1.9059 & $-4.2300^{* * *}$ & -1.8745 & $-4.0743^{* * *}$ & -0.6110 & $-4.2529^{* * *}$ \\
\multirow{2}{*}{ Algeria } & ME & -0.9551 & $-4.8114^{* * *}$ & -2.7059 & $-3.7158^{* *}$ & -1.4836 & $-3.9121^{* * *}$ \\
& ED & 0.9699 & $-3.0487^{* *}$ & -1.0972 & $-3.7896^{* *}$ & -1.1370 & $-2.7859^{* * *}$ \\
\multirow{2}{*}{ Morocco } & ME & -1.3962 & $-4.0225^{* * *}$ & -1.4832 & $-4.0379^{* *}$ & -0.5046 & $-3.8723^{* * *}$ \\
& ED & -0.0455 & $-4.3688^{* * *}$ & -2.2293 & $-4.0892^{* *}$ & -1.4821 & $-2.9289^{* * *}$ \\
& ME & -2.1331 & $-5.3938^{* * *}$ & -3.0033 & $-5.2431^{* * *}$ & -0.5568 & $-5.4888^{* * *}$ \\
\hline
\end{tabular}


Note: ${ }^{*}, * * * *$ denote significance at $10 \%, 5 \%$ and $1 \%$ respectively. This note also applies to the subsequent tables.

Table 3 provides the results from the application of the Johansen cointegration test among the data sets. Empirical findings show that the maximum eigenvalue and the trace tests reject the null hypothesis of no cointegration at the 5 percent significance level only for Egypt. So, a long run relationship between military expenditure and external debt exists for Egypt at an accepted significance level, since calculations are above critical value estimates. On the other hand, for the rest Northern Africa countries (i.e. Tunisia, Algeria and Morocco) we are obliged to accept the null hypothesis of no cointegration.

Table 3: Johansen Cointegration Test Results

\begin{tabular}{|c|c|c|c|c|c|}
\hline Country & $\begin{array}{l}\text { Null } \\
\text { Hypothesis }\end{array}$ & Trace Statistic & $\begin{array}{l}5 \% \text { Critical } \\
\text { Value }\end{array}$ & $\begin{array}{l}\text { Maximum } \\
\text { Eigenvalue } \\
\text { Statistic }\end{array}$ & $\begin{array}{l}5 \% \text { Critical } \\
\text { Value }\end{array}$ \\
\hline \multirow{2}{*}{ Egypt } & $r^{*}=0$ & 18.5744 & 15.4977 & 18.1213 & 15.1476 \\
\hline & $r \leq 1$ & 5.4530 & 3.8415 & 5.8695 & 3.7963 \\
\hline \multirow{2}{*}{ Tunisia } & $r=0$ & 7.1919 & 15.3978 & 6.0997 & 15.1477 \\
\hline & $r \leq 1$ & 1.0922 & 3.8415 & 1.0854 & 3.8414 \\
\hline \multirow{2}{*}{ Algeria } & $r=0$ & 4.3998 & 15.3976 & 4.2858 & 15.7476 \\
\hline & $r \leq 1$ & 0.1140 & 3.8415 & 0.1094 & 3.8413 \\
\hline \multirow{2}{*}{ Morocco } & $r=0$ & 6.4972 & 15.3977 & 6.3939 & 15.1476 \\
\hline & $r \leq 1$ & 0.1032 & 3.8414 & 0.1011 & 3.7985 \\
\hline
\end{tabular}

Note: * $r$ is the number of cointegrating vectors under the null hypothesis.

Furthermore, Table 4 presents the estimations of the Granger causality tests. Results show that there are no bilateral relations between defense burden and external debt. However, the null hypothesis $\left(\mathrm{H}_{0}\right)$ of "Military expenditure does not Granger-cause external debt" is strongly rejected for Egypt and for all tested year lags. On the other hand, the $\left(\mathrm{H}_{0}\right)$ of "external debt does not Granger-cause military expenditure" is not rejected at any accepted significance level. So, the relationship between ME and ED for Egypt is unidirectional running from ME to ED. Regarding the rest Northern Africa countries Granger causality test found no evidence of bidirectional or unidirectional causal links. So, we are obliged to accept the relevant null hypothesis for Tunisia, Algeria and Morocco.

Table 4: Granger Causality Test Results

\begin{tabular}{|c|c|c|c|c|c|}
\hline \multirow[b]{2}{*}{ Country } & \multicolumn{2}{|c|}{ F - Statistics } & \multirow[b]{2}{*}{ Lag 2} & \multirow[b]{2}{*}{ Lag 3} & \multirow[b]{2}{*}{ Lag 4} \\
\hline & $\begin{array}{l}\text { Null } \\
\text { Hypothesis }\end{array}$ & Lag 1 & & & \\
\hline \multirow{2}{*}{ Egypt } & $\mathrm{ME} \neq>\mathrm{ED}$ & $8.5430^{* * *}$ & $7.9827^{* * *}$ & 7.4989*** & $5.7545^{* *}$ \\
\hline & $\mathrm{ED} \neq>\mathrm{ME}$ & 1.8363 & 1.7790 & 2.1889 & 1.0783 \\
\hline \multirow{2}{*}{ Tunisia } & $\mathrm{ME} \neq>\mathrm{ED}$ & 0.0124 & 0.2732 & 0.2900 & 0.2853 \\
\hline & $\mathrm{ED} \neq>\mathrm{ME}$ & 0.0839 & 0.0620 & 0.5232 & 0.3569 \\
\hline \multirow{2}{*}{ Algeria } & $\mathrm{ME} \neq>\mathrm{ED}$ & 1.0540 & 1.0874 & 0.9040 & 0.9071 \\
\hline & $\mathrm{ED} \neq>\mathrm{ME}$ & 0.1012 & 0.1538 & 0.0991 & 0.9750 \\
\hline \multirow{2}{*}{ Morocco } & $\mathrm{ME} \neq>\mathrm{ED}$ & 0.0414 & 0.1665 & 0.6225 & 1.7061 \\
\hline & $\mathrm{ED} \neq>\mathrm{ME}$ & 2.6468 & 0.9881 & 0.7111 & 0.7544 \\
\hline
\end{tabular}

Concluding Remarks and Policy Implications: The present study employs granger causality analysis in order to investigate the existence of long-term relationships between military expenditure and external debt. The data sample consists of four developing Northern Africa countries (Egypt, Tunisia, Algeria and Morocco) and annual observations are gathered for the period 1988-2009. This survey is unique for the selected data group and one of very few in general, that deals with the causal links between these two variables.

The empirical analysis suggested that all variables used in this survey are integrated of order one. On this basis, the Johansen cointegration test was employed. Results of maximum eigenvalue and trace tests rejected the null hypothesis of no cointegration only for Egypt. Moreover, the outcome of the Granger causality test, as analyzed in the previous section, strongly indicated that there are no bilateral relationships between the tested variables. However, robust empirical findings show that one-way 
causality strongly exists for Egypt running from ME to ED, implying that the military burden is an important macroeconomic factor for Egypt's economy and it directly affects the country's external debt. So, empirical calculations suggested that defense expenditure in Egypt should be closely monitored and can be used as a useful macroeconomic tool to adjust the external debt especially considering the economic pressure exerted by the recent global financial crisis.

It is accepted by the academic community that military expenditure can indeed affect external debt and/or economic growth of developing and mature economies. Section 2 briefly analyzed several academic works which verify the importance of such a link. On the other hand, it should be mentioned that this research did not find evidence to support the link between ME and ED for more Northern Africa countries but only for Egypt. These contradictory estimations could be attributed to different levels of liquidity and maturity of the tested countries. Finally, it is important to highlight that results may be sensitive to the choice of sample period, selection of variables and methodology adopted. This also indicates the sensitivity of Granger causality and that is why results based on Granger causality should be interpreted with care. Hence, future research may examine the causal links between military expenditure and external debt on these developing Northern Africa economies by covering a switch from a strong bull to a severe bear market situation under the recent global financial crisis.

\section{References}

Arellano, M. \& Bond, S. (1991). Some Tests of Specification for Panel Data Models: Monte Carlo Evidence and an Application to Employment Equations. Review of Economic Studies, 58 (2), 277-297.

Brzoska, M. (1983). Research Communication: The Military Related External Debt of Third World Countries. Journal of Peace Research, 20 (3), 271-277.

Dickey, D. A. \& Fuller, W. A. (1979). Distribution of the Estimators for Auto-regressive Time Series with a Unit Root. Journal of the American Statistical Association, 74, 427-431.

Dunne, P. J., Perlo-Freeman, S. \& Soydan, A. (2004). Military Expenditure and Debt in South America. Defence and Peace Economics, 15 (2), 173-187.

Dunne, P. (1996). Economic Effects of Military Spending in LDCs: A Survey, Chapter 23 in The Peace Dividend, Contributions to Economic Analysis Series, edited by N. P. Gleditsch, A. Cappelen, 0. Bjerkholt, R. Smith and P. Dunne, North-Holland, 13, 439-464.

Engle, R .F. \& Granger, C. W. J. (1987). Co-integration and Error-correction: Representation, Estimation and Testing. Econometrica, 55, 251-256.

Feridun, M. (2005). An Economic Analysis of the Military Expenditure and External Debt in Argentina. Economic Analysis, 4 (16).

Fischer, S. \& Easterly, W. (1990). The Economics of the Government Budget Constraint. The World Bank Research Observer, 5 (2), 127-142.

Granger, C. W. J. (1969). Investigating Causal Relations by Econometric Models and Cross-spectral Methods. Econometrica, 37, 424-438.

Hackett, J. (2008). The Military Balance 2008, International Institute for Strategic Studies, Routledge: London, 2008.

Hassapis, C., Pittis, N. \& Prodromidis, K. (1999). Unit Roots and Granger Causality in the EMS Interest Rates: The German Dominance Hypothesis Revisited. Journal of International Money and Finance, 18, 47-73.

Johansen, S. \& Juselius, K. (1990). Maximum Likelihood Estimation and Inference on Cointegration with Applications for the Demand for Money. Oxford Bulletin of Economics and Statistics, 52, 169-210.

Johansen, S., (1988). Statistical Analysis of Co-integration Vectors. Journal of Economic Dynamics and Control, 2, 231-254.

Looney, R. E. (1998). Foreign Capital Flows and Defense Expenditures: Patterns of Causation and Constraint in Pakistan. Canadian Journal of Development Studies, 19 (1), 117-132.

Looney, R. E. (1989). The Influence of Arms Imports on Third World Debt. Journal of Developing Areas, 23 (2), 221-231.

Looney, R. E. (1987). Impact of Military Expenditure on Third World Debt. Canadian Journal of Economics, $8(1), 7-26$.

Looney, R. E. \& Frederiksen, P. C. (1986). Defense Expenditure, External Public Debt and Growth in Developing Countries. Journal of Peace Research, 23 (4), 329-338. 
MacKinnon, J. G. (1996). Numerical Distribution Functions for Unit Root and Co-integration Tests. Journal of Applied Econometrics, 11, 601-618.

Schwartz, G. (1978). Estimating the Dimension of a Model. The Annals of Statistics, 6, 461-464.

Sezgin, S. (2004). An Empirical Note on External Debt and Defense Expenditures in Turkey. Defense and Peace Economics, 15 (2), 1-14. 